\title{
O lugar da aprendizagem narrativas de uma experiência de representações e percepções culturais
}

\section{GENILDA ALEXANDRIA}

Resumo

Este projeto tem por objetivo problematizar uma experiência de educação patrimonial, planejada e aplicada em 2008, para professores das redes de ensino formal da cidade de Goiânia. Fundamenta-se na escolha de um percurso no centro da cidade, a que se denominou Vila Cultural, como lugar de aprendizagem, do viver, conhecer, socializar e ser. Problematizar a experiência da ação educativa do referido projeto implica rever as práticas pedagógicas por meio do olhar da educação para a cultura visual. Proponho a formação de um grupo focal entre os professores envolvidos nesse projeto para investigar os desdobramentos das experiências nas práticas educativas. Assim, busco analisar o que se convencionou chamar de patrimônio tendo em perspectiva os sentidos de descoberta e apropriação inerentes a contextos e práticas sociais.
Palavras-chave:

Goiânia, educação patrimonial, cultura visual 